\title{
Laying a Legend to Rest: The Poet Kapnist and Ukraino-German Intrigue
}

For seventy-five years a furiously controversial legend has hung over the name and reputation of the eighteenth-century Russian poet Vasilii Vasilievich Kapnist. It began at a meeting of the Polish Historical Association on December 7, 1895, when Professor Bronisław Dembiński, of the University of Lwów, read a report about his discovery of a document in the Preussisches Geheimes Staatsarchiv stating that a Ukrainian gentleman named Kapnist had secretly gone to Berlin in April 1791 and talked with the Prussian minister of state, Count Ewald-Friedrich Hertzberg, about the Ukrainians' desire to get Prussian help in freeing themselves from Russia. Professor Dembiński's paper, published in $1896,{ }^{1}$ was promptly brought to the attention of Ukrainian readers by the Ukrainian historian M. S. Hrushevsky, who expressed the opinion that the Kapnist who secretly visited Berlin was "undoubtedly none other than the well-known author of Chicanery [Kapnist's comedy Iabeda]."2

Since then the story has had a curious way of turning up over and over again under suspicious circumstances of time and place. The Ukrainian V. Doroshenko resurrected it at a crucial moment during the First World War in his book Ukrainstvo $v$ Rosii, which appeared in Vienna in 1917. On page 4 he referred without giving any sources to "the glorious patriots at the end of the eighteenth century, the defenders of Hetman autonomy, who in 1791 sent Vasylii Kapnist to Germany to seek aid against the 'Russian tyranny,' which had just then brutally struck down Ukrainian freedom." In 1939, on the eve of the Second World War, Mykhailo Antonovych repeated Dembiński's story. ${ }^{3}$ After the Second World War the Kapnist who took the secret trip to Berlin in 1791 was identified as the poet Vasilii Kapnist by both T. Ciuciura and the eminent Slavist Dmitrij Tschižewskij.4

This interpretation of the Prussian archive document on Kapnist was indignantly rejected in 1958 by A. Matsai, who declared: "The provocative

1. Bronisław Dembiński, "Tajna misja ukraińca w Berlinie w r. 1791," Przeglqud Polski (Kraków), 3 (1896): 511-23.

2. "Sekretna misiia ukraintsia v Berlini r. 1791," Zapysky Naukovoho tovarystva im. Shevchenka, 9 (1896): 7-9, "Miscellanea." $16-22$.

3. "Kozats'kyi proiekt Vasylia Kapnista," S'ohochasne i mymule (L'viv), 2 (1939):

4. Ukrainian Concise Encyclopedia, vol. 1 (Toronto, 1963), pp. 667 and 943. 
twaddle spread by bourgeois Ukrainian nationalists in the wake of $M$. Hrushevsky about V. V. Kapnist's enmity toward Russia and her people, and about his trip in 1791 'to Germany to ask for help against Russia,' has nothing in common with reality and is false from beginning to end. This has been proved by the most recent historical research." The only "historical research" he cites to support his statement is a 1947 article by L. Kovalenko in which the author merely states without proof that the Kapnist who went to Berlin in 1791 was the poet's brother Peter. ${ }^{8}$

In 1959 the late Professor P. N. Berkov, of Leningrad, denied with equal vehemence that the Prussian archive document referred to the poet. Calling attention to "the old version [of V. V. Kapnist's relation to the Ukraine] advanced in the 1890s by the Polish researcher Bronisław Dembowski [sic] and picked up after that by Ukrainian nationalists," Berkov declared: "All these slanderous fabrications have now been refuted. It turned out that Kapnist never traveled beyond the frontiers of Russia, and this referred not to Kapnist but to another person, for whose actions the poet was not responsible."?

Berkov did not go beyond this cryptic remark to tell us either who had refuted the "slanderous fabrications" about the poet or who the "other person" was, but it seems clear that he too had in mind the poet's brother Peter Vasilievich. P. V. Kapnist had first been proposed in 1910 by V. L. Modzalevsky as the Kapnist of the Prussian document. In the footnote to his genealogy of the Kapnist family Modzalevsky quoted Hrushevsky's account of the secret Berlin visit and then went on to declare that Hrushevsky's source "would scarcely withstand rigorous historical criticism."

Unfortunately, Modzalevsky's account of P. V. Kapnist's biography also fails to withstand rigorous historical criticism. According to Modzalevsky, Peter Vasilievich retired from the Preobrazhensky Regiment in 1775 and "wandered about for several years in foreign lands: he first went to Holland; he spent the years of the Revolution (1789-93) in France; after the execution of King Louis XVI, in whose bodyguard he had been enrolled, he settled in England, where he married an English girl." collection of 271 letters written by Vasilii Kapnist, most of them to members of his family, shows conclusively that Peter Vasilievich had married his English wife and settled with her in the Ukraine as early as 1781, and that he was living on his estate in the Ukraine in $1783,1785,1786,1787,1788$,

5. A. Matsai, "Iabeda" V. V. Kapnista (Kiev, 1958), p. 78.

6. L. Kovalenko, "O vliianii frantsuzskoi revoliutsii na Ukrainu," Voprosy istorii, 1947, no. 2, p. 83.

7. P. N. Berkov, "V. V. Kapnist kak iavlenie russkoi kul'tury," in XVIII vek: Sbornik, vol. 4 (Moscow and Leningrad, 1959), p. 264.

8. V. L. Modzalevsky, Malorossiiskii rodoslounik, vol. 2 (Kiev, 1910), pp. 284-85. 
throughout the first half of 1789 , in January 1791 , and every year from 1792 until Catherine's death in $1796 .{ }^{\circ}$

In 1931, in his notes to the memoirs of Sofiia Vasilievna Kapnist-Skalon, the daughter of the poet, the late Iu. G. Oksman also identified the Kapnist of the secret Berlin journey as Peter Vasilievich and repeated Modzalevsky's account of P. V. Kapnist's wanderings abroad, adding to it the equally untenable statement that Kapnist had returned home to Russia only after Paul I had succeeded Catherine II as ruler in 1796. Professor Oksman identified P. V. Kapnist's English wife as "Elizaveta Timofeevna Gausman," evidently the daughter of a Timothy Housman, who according to the Kapnist family tradition managed to spend the rest of her life in the Ukraine without ever learning Russian. ${ }^{10}$

Modzalevsky's and Oksman's identification of Peter Vasilievich as the Kapnist of the secret Berlin journey was repeated in 1937 by the Ukrainian Ilko Borshchak in a book published in Poland ${ }^{11}$ and ten years later by Kovalenko in the article already cited.

In 1941, through a coincidence that can scarcely have been accidental, the German Zeitschrift für slavische Philologie published an article by Georg Sacke in which he revived the theory that it was the poet Vasilii Kapnist who had sought the help of Prussia in freeing the Ukraine from the Russians. Sacke also published the text of the documents that Dembiński had first discovered nearly fifty years earlier in the Preussisches Geheimes Staatsarchiv. ${ }^{12}$ The first of these documents, dated "Berlin le 24. Avril 1791" and addressed in not entirely idiomatic French by the Prussian Count Hertzberg to the Prussian Emperor Friedrich-Wilhelm II, contains the following information about his Ukrainian visitor:

Je crois devoir très humblement rapporter à V. M. qu'il vient de se présenter chez moi en secret un gentilhomme de la Petite-Russie ou Ukraine Russienne, qui s'appelle de Kapnist, et qui se dit être un gentilhomme possessionné dans ce pays-là, et qui avait le titre de Conseiller de Cour et même un emploi dans les fabriques. Il prétend être envoyé par les habitants de ce pays-là, qui étoient poussés au dernier désespoir par la tirannie, que le gouvernement Russien, et nommément le P-ce Potemkin exerçoient sur eux et qu'il souhaitoit de savoir, si en cas de guerre, ils

9. V. V. Kapnist, Sobranie sochinenii $v$ dvukh tomakh, ed. D. S. Babkin (Moscow and Leningrad, 1960); hereafter cited as SS.

10. Iu. G. Oksman and S. N. Chernov, eds., Vospominaniia $i$ rasskazy deiatelei tainykh obshchestv 1820-kh godov, 2 vols. (Moscow, 1931-33), 1:407-8; this volume is hereafter cited as Oksman.

11. Ilko Borshchak, Napoleon i Ukrainna (L'viv, 1937), p. 123.

12. Georg Sacke, "V. V. Kapnist und seine Ode 'Na rabstvo," Zeitschrift für slavische Philologie, 17 (1941): 291-301. 
pourroient se flatter de la protection de S. M. dans lequel cas ils tacheroient de secouer le joug Russien. Il dit que c'étoit le pays des anciens Cosaques Zaporoviens, aux quels on avoit ôté tous leurs Privilèges en les mettant sur le pied des Russes; qu'on eu formé 28 Régiments de Cavallerie chacun de 800 hommes, qui servoient la Russie très malgré eux et ne demandoient pas mieux que pouvoir rétablir l'ancienne Constitution des Cosaques; que l'Imp-ce en avoit formé les 5 gouvernements de Catherinoslaw, de Karchow, de Kyowie etc. Cet émissaire a assez bonne mine et m'a parlé d'une manière assez prévenante. ...

Hertzberg went on to report that he had answered his visitor noncommittally, telling him that if war should break out between Prussia and Russia it would then be up to the Cossacks to decide whether they wished to get in touch with the King of Prussia. "Le Sr Kapnist m'a dit là-dessus," said Hertzberg, "qu'il retourneroit chez lui, qu'il avoit un frère, qui voyagoit [sic] et qui pourroit se présenter ici le cas existant [sic]." In a footnote Hertzberg added suspiciously: "Il est à craindre, que ce ne soit un émissaire aposté par la Cour de Russie et envoyé pour sonder ici le terrain, quoiqu'il n'en ait pas la mine exterieure."

Sacke disputes Oksman's assertion that this report refers to Peter Kapnist rather than to the poet, calling attention to the fact that Hertzberg identified his visitor as a "Conseiller de Cour" (nadvornyi sovetnik) with "un emploi dans les fabriques," and that Vasilii Kapnist was indeed a nadvornyi sovetnik and at one time held a position in the administration of a silk factory in Kiev, whereas his brother Peter had retired from the army with the rank of only an ensign. (Sacke calls him a "Leutnant," evidently confusing praporshchik with podporuchik.)

Even though V. V. Kapnist's published letters disprove the earlier belief that his brother Peter lived abroad from the 1770s until Catherine's death in 1796 , and even though they show that he was on his Ukrainian estate in January 1791, they of course do not prove that he was in the Ukraine the following April, when someone named Kapnist paid the secret visit to Berlin. Nevertheless, there are good reasons why the secret emissary could not have been Peter. The first and strongest is that his rank did not correspond to that of the court councilor (nadvornyi sovetnik) described by Hertzberg. The second is Hertzberg's statement that the secret emissary had told him "he had a brother who traveled, and who could report here if the need should arise." Since Peter Kapnist was married to an Englishwoman and quite possibly returned with her to England from time to time, he is very likely the brother to whom the emissary referred in this statement.

But if we eliminate Peter Kapnist as the secret emissary, does not this force us after all to accept the charge of "high treason" against the Russian state that Georg Sacke leveled at the poet Vasilii Kapnist just after Nazi 
Germany's attack on the Soviet Union had inaugurated the new twentiethcentury fashion of invading one's allies? Some of the evidence presented by Sacke is indeed disturbingly persuasive. The Kapnist who paid the secret visit to Berlin held the same government rank as the poet: both were court councilors. The memoirist F. F. Vigel is quoted by Sacke as saying that although Kapnist was married to the sister-in-law of the great Russian poet Derzhavin, "even these marital ties could not bind him to Russia," and that Kapnist and his fellow Ukrainian poet Gnedich, "despite the unity of faith and blood and name, despite the 200-year-old union of their native land with Russia, secretly hated it and the Russians, the Muscovites." ${ }^{13}$ In further support of his position Sacke went on to argue that Kapnist's famous "Ode on Slavery" was not really directed against Catherine's enslavement of the Ukrainian peasants at all, but rather against her enslavement of the whole Ukrainian nation.

In the face of this evidence, what can be said in defense of Vasilii Kapnist against the rumors of his patriotic Ukrainian "high treason" against the Russian Empire? First of all, even though the testimony of F. F. Vigel can be dismissed as the judgment of a man who lacked real firsthand knowledge of Kapnist, there is no doubt about the poet's strong attachment to the Ukraine. According to D. N. Bantysh-Kamensky, Kapnist spoke fluent French and German as well as Russian but "he liked for the most part to speak Little Russian and in this way would enhance the pleasure produced by his narration, which was interesting and comical at the same time" (Oksman, p. 400). This attachment to the Ukraine was shared by the whole Kapnist family. When the poet married a Russian girl and took her home with him to the Ukraine, his mother called her a "Muscovite" and was slow to accept her fully. In the home of his eldest brother, Nikolai, the language most commonly spoken was Ukrainian (pp. 301, 314).

The poet's daughter says in her memoirs: "My father passionately loved his native land and was ready to sacrifice everything he owned for the welfare of Little Russia; upon the slightest oppression or injustice on the part of government officials he would fly to Petersburg, leave his family, contract debts (which, incidentally, would be secretly repaid by his close friend and brother Peter Vasilievich), and after struggling often with illustrious personages, would almost always come back the victor" (p. 304). Elsewhere in her memoirs she writes: "In general he took a lively interest in everything that concerned Little Russia, and suffered, one might say, along with her, as a result of which he was for the most part melancholy and in a bad humor. His one desire was to restore Little Russia's former prosperity and wealth,

13. Sacke, "V. V. Kapnist," p. 294 ; F. F. Vigel, Zapiski, 7 vols. in 3 (Moscow, 1891-93), 3:145-46. 
and as it were to revive the common people, who still remembered their freedom but were oppressed and persecuted by the injustices of the police of that time" (p. 311).

Sacke cites these passages in support of his argument that the Kapnist who took the secret trip to Berlin was the poet. He then goes on to explain away the evidence that contradicts his theory by declaring that the poet's "separatist endeavors, as they were expressed in his 'Ode on Slavery' and especially in his Berlin negotiations with Hertzberg, appear to have been only an episode in Kapnist's life, which he did not like to recall. In subsequent years he never again undertook any actions in the nature of high treason. He obviously became convinced that his homeland could also flourish within the framework of the Russian state. Partly through conviction and partly through practical considerations he drew closer to the Russians and the Russian government."14

The most charitable assessment of Sacke's arguments is that he advanced them without the benefit of the 271 Kapnist letters that have since been published. Whether they would have substantially changed the conclusions that Sacke published in the year 1941 is of course a question that would carry us beyond the confines of literature.

These letters give us numerous glimpses into Vasilii Kapnist's state of mind throughout the more than forty years of his adult life. Of the first 126 letters, covering the period through 1796,101 were written to his wife, almost invariably with the request that she pass them on to his brother Peter, and sixteen of the remaining twenty-five were addressed to this same brother. (His letters to them both are almost entirely in his fluent foreign French, with Russian syntax showing through on almost every page.)

In 1786, the year after Vasilii Kapnist had been elected marshal of the nobility for the Kiev Province, he wrote to his wife and brother about his visit to the governor-general in Kiev and the plans for Catherine II's approaching visit of state to her southern provinces $(S S, 2: 289-99)$. On February 23, 1787 , he wrote in great excitement about having been presented to Her Majesty that morning (2:301). A year later, when the Russian armies in the south were still reeling under the attack that Turkey had launched in the summer of 1787 and when Petersburg was threatened by the Swedish armies to the north, Vasilii Kapnist hurried off to the capital for the dual purpose of complaining on behalf of the nobility of Ekaterinoslav Province against the provincial bureaucrats, and presenting a plan to the empress for the organization of a volunteer army from among the half-million Cossacks whose military units had been abolished in 1775 through Catherine's fear of Ukrainian separatism. After his arrival in Petersburg he proudly reported in a letter to his wife: "The Empress, on coming here from Kiev, spoke very much in my favor

14. Sacke, “V. V. Kapnist," p. 299. 
to Count Vorontsov. She said she had found only one man in Little Russiame" (2:316). Two weeks later, when his plan to organize the Cossack militia had been rejected, he wrote to his brother Peter expressing relief at being "freed of the burden of enrolling the Cossacks" and went on to urge his brother to get everything in order so that the two of them could leave for the south and join Prince Potemkin's army as volunteers-a project they did not carry out, by the way $(2: 320-21)$.

Six letters have been published that were written by the poet from Kiev to his wife and his brother Peter in January and February 1791-less than three months before the mysterious Berlin visit of the Ukrainian named Kapnist. The tone of these six letters is scarcely what one would expect to be used either by or to a man who was about to depart on a mission of that nature. Over and over the poet exclaims about the favor shown to him by the new governor-general of Kiev, Mikhail Nikitich Krechetnikov. "Every day he keeps repeating that he wants to keep me here," Kapnist wrote to his wife on January 12. In his next letter, written a week later, he said: "I am pleased no end with the good graces of the Governor-General, and the way he overwhelms me with kindness and distinctions. It is quite evident that he wants to attach me to himself with all sorts of attention. All my enemies have bitten the dust. ... I visit the Governor-General every day and every evening, and he always makes me stay for dinner. Everybody around him seeks my friendship. But I can't tell you how pleased I am with him $(2: 350-51)$. In a letter written on the same day to his brother Peter he gives the latest news:

Prince Potemkin is going to Petersburg by way of Moscow. Vasilii Stepanovich [General Popov, Potemkin's chief of staff] will be here soon. Izmail cost dear [a reference to Suvorov's sensational victory over the Turks a month earlier]. Bezborodko [Count Alexander Andreevich] was wounded, but not seriously. The Poles are silent. It is thought that the Prince [Potemkin] on his return will be in Kiev. God grant that he has brought peace with him. For the rest, the best news is that Mikhail Nikitich [Krechetnikov] is taking on all parts of the administration in such a way that we shall soon taste the very good fruits of his labor. $\mathrm{He}$ is an excellent man. For all the good things I had heard about him, I now see twice as many. If he had been here from the beginning of the provincial system, we would be both enlightened and happy. God grant that he may stay here a long time. ${ }^{15}$

(2:352-53)

If any further evidence from Kapnist's letters were necessary in order to demonstrate that he was incapable of the kind of Ukrainian separatist intrigue reported by the Prussian Minister Hertzberg, the following quotation from his letter of April 15, 1793, written in Petersburg to his wife, should be

15. The addressee of this letter is given as Kapnist's wife, but this is evidently a typographical error. 
sufficient: "Today at the big meeting of the Senate the manifesto about our taking a part of Poland will be read, and the Sovereign will be thanked by the Senate on behalf of all Russia. Thus I hope that since she has reason to be satisfied with events, she will be well disposed toward listening to requests, and among others to mine through Gavrilo Romanovich [Derzhavin, the poet, whose wife was Kapnist's sister-in-law]" (2:372). The request that so evidently preoccupied Kapnist here far more than Russia's partition of a neighboring Slavic country was his request to be relieved of responsibility for managing a state-owned silk mill in Kiev (2:582).

If neither the poet Vasilii nor his brother Peter was the Kapnist who took the secret trip to Berlin in 1791, then who was? Before answering that question, let us review the facts that must be taken into account. The Hertzberg document in the Prussian State Archives informs us that the secret emissary was a Ukrainian named Kapnist, that he held the rank of court councilor (nadvornyi sovetnik), that he had some kind of "employment in factories," and that he had a brother who traveled abroad. There can be no doubt that the mysterious emissary was a close relative of the poet, because the name "Kapnist" originated with the poet's father, Vasilii Petrovich, a Greek named Kapnissis from the island of Zante who took refuge in Russia from the Turks in 1711, subsequently rose to the rank of brigadier in the Russian army, and acquired a number of estates in the Ukraine. V. P. Kapnist was married twice: first to the daughter of a wealthy Greek merchant named Sogden, by whom he had two sons, Daniil and Ananii; and then to Sofiia Andreevna Dunin-Borkovskaia, a Ukrainian of remotely Polish origin, who bore him four more sons, the youngest of whom was the future poet Vasilii. ${ }^{16}$

As far as can be learned from historical records, V. P. Kapnist's eldest son Daniil died some time before 1760 and left only one son, Ivan, whose rank of second lieutenant (podporuchik), corresponding to the civilian rank of provincial secretary, disqualifies him as the secret Berlin emissary. The second son, Ananii, had only one child, a daughter. Among V. P. Kapnist's four sons by his second wife, we have already disqualified Vasilii and Peter as candidates for the secret Berlin mission, and we can also disqualify Andrei, who retired

16. Modzalevsky, Malorossiiskii rodoslownik, 2:282-93; and A. B. Lobanov-Rostovsky, Russkaia rodoslovnaia kniga, 2 vols. (St. Petersburg, 1895), 1:237-39. In reality, there is some doubt whether he really was the son of his father's second wife. The poet's great-great-granddaughter, M. R. Kapnist, told the late Professor Berkov that according to family tradition Vasilii Kapnist was born on February 23, 1756, exactly two years before the date given by the poet himself, and was the illegitimate son of V. P. Kapnist and a captive Turkish girl. When V. P. Kapnist was killed in battle in 1757, the family tradition relates that his captive Turkish paramour committed suicide and his legal wife took the baby Vasilii and brought him up as her own son (see Berkov, "V. V. Kapnist," pp. 25758). If this story is true, then the Ukrainophile poet Kapnist who wrote in Russian had no biological connection with either the Ukrainians or the Russians: he was half-Greek and half-Turkish. 
from military service early in life with the rank of second lieutenant and soon went insane. This leaves only the eldest brother, Nikolai. Apparently no one has ever suggested that Nikolai Vasilievich might have been the Kapnist who took the secret journey to Berlin in April 1791; and in view of the evidence this appears to be an astonishing oversight. After getting a good education in Petersburg along with his brothers, Nikolai returned to the Ukraine, made an unhappy marriage in 1783, and settled down on one of the family estates at Manzheleia, about seventy-five miles from the family center at Obukhovka. There his unloved wife eventually bore him five daughters and a son. Sofiia Kapnist-Skalon, the poet's daughter, described her uncle Nikolai in her memoirs as "an intelligent man, but with great eccentricities; he thought so much about himself and his intelligence that he spoke in no other way than through some kind of often completely incomprehensible allegories, and it would astonish him whenever people in his own family did not understand him." Sofia Vasilievna characterized her uncle as a great family despot, who spoiled his favorite daughter, neglected his wife and the rest of his children, and imposed his own strict religious piety on all the rest of his household. He was very well-to-do, and once, around 1805 , took his whole family abroad for a period of two years. ${ }^{17}$

The eccentric Nikolai was not as close to his genial, outgoing brothers Vasilii and Peter as they were to each other; but still the three brothers and their families did get together on each of their three estates at least once every year to celebrate some family name day. The memoirist reports a conversation at one of these family gatherings, in 1812 , which provides this remarkable support for the candidacy of Nikolai as the secret Berlin emissary:

Once, in 1812, I was extremely surprised by an opinion of Uncle Nikolai Vasilievich, who turned to my father and very seriously asked him in these words:

"Tell me, Vasilii Vasilievich, what will you do if Bonaparte comes into Little Russia? What will be your plans, and which way will you run?"

My father answered:

"I do not intend to go anywhere: knowing Little Russia well and being loved by it, I hope to call it to arms, provide it with weapons, and drive him 'beyond our frontiers in shame."

"And I don't think like that at all," said Nikolai Vasilievich. "I will go out to meet him myself, and I'll offer that intelligent man the bread and salt of hospitality."

You can imagine the astonishment of my father and Uncle Peter Vasilievich at such an original opinion-and precisely at the time when

17. Oksman, pp. 314-16. This view of Nikolai is also found in the biography of the poet's grandson, Peter Ivanovich Kapnist, written by his daughter Ina Petrovna, who described Nikolai as "the least sympathetic of the brothers," an eccentric, and a family despot (Peter Ivanovich Kapnist, Sochineniia, 2 vols. [Moscow, 1901], 1:xv). 
everybody was terrified lest Napoleon should invade Little Russia! But Uncle Nikolai Vasilievich's escapades and original opinions always set him apart. ${ }^{18}$

We know very little about Nikolai Kapnist apart from the memoirs of his niece and the scanty information given in Modzalevsky's genealogy, but none of the available information conflicts with the theory I advance here that he was the Kapnist who made the secret journey to Berlin in April 1791. As I have already shown, the same thing cannot be said about either Vasilii or Peter. As a wealthy, intelligent eccentric with strong Ukrainian sympathies, Nikolai was fully capable of undertaking a secret journey to Berlin without letting anybody - even his brothers-know what his real intentions were, or even exactly where he was going. And once he had the ear of Hertzberg, his eccentricity and his way of talking in "some kind of often completely incomprehensible allegories" made him capable of picking up odd bits of reality and using them to convey an entirely different impression to the Prussian minister. His brother Vasilii's frustrated plan for a volunteer Cossack army to defend the Russian Empire against the Turks may well have provided the inspiration for a fantasy of his own about a separatist Ukrainian army, in which he displaced his better-known younger brother as the principal hero. His reference to himself as having a position in factories may have had some basis in factbut again it may have been a fantasy inspired by his brother's responsibility for the silk mill in Kiev. Nikolai's statement to Hertzberg about his brother who traveled probably reflects more frequent visits to the West by Peter and his English wife than the available records now show, but we have no reason to think that Peter was necessarily aware of the role that Nikolai had prepared for him in his talk with Hertzberg. All in all, the most likely explanation for the secret mission described in Hertzberg's report to the Prussian emperor is simply that it was nothing more than an eccentric single-handed escapade by the erratic Nikolai Kapnist. His brothers may very well have lived and died without finding out as much about it as we know today from the Hertzberg document.

One final bit of evidence in support of Nikolai as the secret emissary is Hertzberg's unequivocal statement that the Kapnist who visited him held the government rank of court councilor. Except for the poet Vasilii, whom I have already eliminated from consideration on the basis of his own statements in his letters, there was only one other member of the whole Kapnist family who held the rank of court councilor in the eighteenth century. That person was the poet's eccentric brother Nikolai. ${ }^{10}$

18. Oksman, p. 320 .

19. SS, 2:441; Modzalevsky, Malorossiiskii rodoslovnik, 2:284. 